\title{
Pelatihan Deteksi Dini Kelainan Tumbuh Kembang Anak bagi Kader Posyandu di Desa Bulubrangsi Kecamatan Solokuro Lamongan
}

\author{
Kustini*, Kaka Nursaida Sandana \\ Program Studi Diploma III Kebidanan, Sekolah Vokasi, Universitas Islam Lamongan \\ *Correspondent Author: custiniwil@gmail.com
}

\begin{abstract}
ABSTRAK
Kelainan atau penyimpangan tumbuh kembang anak dapat dikendalikan sejak awal. Istilah tumbuh kembang mencakup daua peristiwa yang sifatnya berbeda tetapi saling berkaitan dan sulit dipisahkan, yaitu pertumbuhan dan perkembangan.Pertumbuhan ( growth) berkaitan dnegan masalah perubahan ukuran, besar, jumlah atau dimensi tingkat sel, organ, maupun individu, yang bisa diukur dengan ukuran berat, ukuran panjang, umur tulang, dan keseimbangan metabolic ( retensi kalsium dan nitrogen dalam tubuh ). Perkembangan (development ) adalah pertambahan kemampuan ( skill) dalam struktur tubuh yang lebih kompleks dalam pola yang teratur dan dapat diramalkan, sebagai hasil dari proses pematangan

Tujuan dari Pengabdian masyarakat ini adalah Meningkatkan pengetahuan ibu - ibu dalam melakukan praktek pola asuh gizi anak balita melalui kegiatan pelatihan, mengembangkan keterampilan ibu - ibu dalam melakukan praktek penyusunan makanan higienis mengacu pedoman gizi seimbang khususnya pemenuhan kebutuahn protein menggunakan teknik komplementer zat gizi dan memanfaatkan pangan lokal melalui pelatihan, menambah wawasan ibu - ibu dalam hal kemampuan dasar manajeman curahan waktu ibu untuk pemeliharaan kesehatan balita dan stimulasi psiko- social

Metode yang digunakan adalah Ceramah tentang kelainan tumbuh kembang anak serta pencegahan dan penaggulangannya, Diskusi dengan Tanya jawab materi yang telah dipaparan waktu ceramah dan Lomba dalam mengerjakan pre-test dan post-tes

Hasil dari pengabdian masyarakat ini adalah Ada peningkatan pengetahuan ibu - ibu kader posyandu tentang deteksi dini kelainan tumbuh kembang anak, terbukti sebagian besar ibu - ibu peserta pelatihan mendapatkan nilai post -test lebih tinggi dibanding pre-test.
\end{abstract}

Kata Kunci: Pelatihan Deteksi Dini Kelainan Tumbuh Kembang Anak, Kader Posyandu

Received: July 8, 2021

Revised: August 10, 2021

Accepted: September 1, 2021

This is an open-acces article distributed under the terms of the Creative Commons Attribution-ShareAlike 4.0 International License.

\section{PENDAHULUAN}

Kelainan atau penyimpangan tumbuh kembang anak dapat dikendalikan sejak awal. Istilah tumbuh kembang mencakup daua peristiwa yang sifatnya berbeda tetapi saling berkaitan dan sulit dipisahkan, yaitu pertumbuhan dan perkembangan.Pertumbuhan ( growth) berkaitan dnegan masalah perubahan ukuran, besar, jumlah atau dimensi tingkat sel, organ, maupun individu, yang bisa diukur dengan ukuran berat, ukuran panjang, umur tulang, dan keseimbangan metabolic ( retensi kalsium dan nitrogen dalam tubuh ). Perkembangan (development ) adalah pertambahan kemampuan ( skill) dalam struktur tubuh yang lebih kompleks dalam pola yang teratur dan dapat diramalkan, sebagai hasil dari proses pematangan. Disini menyangkut adanya proses diferensiasi dari sel - sel tubuh, jaringan tubuh, organ - organ, dan system oragan yang berkembang sedemikian rupa sehingga masing - masing dapat memenuhi fungsinya. Termasuk juga 


\section{Journal of Community Engagement in Health}

perkembangan emosi, intelektual, dan tingkah laku sebagai hasil interaksi dengan lingkungan. Artinya, pertumbuhan mempunyai dampak terhadap aspek fisik, sedangkan perkembangan berkaitan dengan pematangan fungsi organ/individu ( Soetjiningsih, 1998)

Gizi merupakan salah satu factor yang berpengaruh terhadap proses tumbuh kembang pada anak. Sebalum lahir, anak tergantung pada zat - zat gizi yang terdapat dalam darah ibu. Setelah lahir, anak tergantung pada tersedianya bahan makanan dan kemampuan saluran cerna. Gizi memegang peranan penting dalam tumbuh kembang anak, dimana kebutuhan anak - anak berbeda dengan kebutuhan orang dewasa, karena anak - anak masih dalam masa pertumbuhan. Hasil penelitian tentang pertumbuhan anak Indonesia ( Sunawang, 2002), Menunjukkan bahwa kegagalan pertumbuhan paling gawat terjdi pada anak usia 6-18 bulan. Setelah dianalisis, ternyata penyebab gagal tumbuh tersebut dapat ditelusuri sejak anak di dalam kandungan ibu/ keadaan gizi ibu saat hamil dan disebabkan pula oleh pola makan bayi serta adanya penyakit infeksi.

Tumbuh kembang anak yang sudah dimulai sejak bertemunya sperma dan sel telur sampai dewasa itu mempunyai ciri - ciri tersendiri, proses yang kontinyu sejak dari mudugah sampai maturitas /dewasa, yang dipengaruhi oleh factor bawaan dan lingkungan. Ini berarti bawha tumbuh kembang sudah terjadi sejak didalam kandungan dan setelah kelahiran merupakan suatu masa periode tertentu terdapat adanya masa percepatan atau masa perlambatan, serta laju tumbuh kembang yang berlaianan diantara organ - organ. Terdapat 3 periode pertumbuhan cepat adalah pada masa janin, masa bayi $0-1$ tahun dan masa pubertas. Sedangkan pertumbuhan organ - organ tubuh mengikuti 4 pola, yaitu pola umum, limfoid, neural dan reproduksi .

\section{BAHAN DAN METODE}

Metode Kegiatan Pengabdian kepada masyarakat adalah menggunakan Ceramah tentang kelainan tumbuh kembang anak serta pencegahan dan penaggulangannya, Diskusi dengan Tanya jawab materi yang telah dipaparan waktu ceramah, Lomba dalam mengerjakan pre-test dan post-tes, Populasi terdiri dari Masyarakat desa bulubrangsi Kecamatan Laren Kabupaten Lamongan yang terdiri dari Ibu - ibu kader Posyandu sejumlah 20 orang. Langkah - langkah Kegiatan PPM, Peserta pelatihan mengerjakan pre- test, Peserta pelatihan mendapatkan paparan materi kelainan tumbuh kembang anak, Peserta pelatihan dan permateri melakukan diskusi dengan Tanya jawab masalah kelainan tumbuh kembang anak., Peserta pelatihan mengerjakan post-tes, Peserta pelatihan melakukan pendeteksian kelainan - kelainan tumbuh kembang anak dengan praktek di Posyandu

\section{HASIL}

Pelatihan yang melibatkan 20 kader kesehatan posyandu tersebut secara garis besar menunjukkan hal yang menggembirakan yaitu $100 \%$ peserta merespon positif dalam hal kemanfatan yang sangat tinggi untuk melakukan deteksi dini kelainan tumbuh kembang anak. Sedangkan hasil tes baik pre-test maupun post-test dapat disajikan pada tabel berikut

Tabel. 1 Hasil evaluasi pengetahuan tentang tumbuh kembang anak (pretest dan post-test)

\begin{tabular}{|l|l|l|l|}
\hline No & Katagori Nilai & Jumlah peserta & persentase \\
\hline 1 & Ada peningkatan & 16 & $80 \%$ \\
\hline 2 & Tidak ada peningkatan & 4 & $20 \%$ \\
\hline Jumlah & 20 & $100 \%$ \\
\hline
\end{tabular}

Nilai pretest dan post - test menunjukkan perubahan berupa peningkatan nilai pada 16 orang kader ( $80 \%)$ dan 4 orang kader $(20 \%)$ tidak menunjukkan peningkatan nilai sedang praktek pendeteksian kelainan tumbuh kembang anak dengan mencatat kelainan fisik dan psikis yang ditemukan di KMS yang dilakukankan para kader di Posyandu dapat dilihat pada tabel berikut ini. 
Table 2. hasil evaluasi ketrampilan kader posyandu dalam mendeteksi kelainan tumbuh kembang anak

\begin{tabular}{|l|l|l|l|}
\hline No & Katagori nilai & Persentase & Jumlah peserta \\
\hline 1 & Mampu & 20 & $100 \%$ \\
\hline 2 & Tidak mampu & 0 & $0 \%$ \\
\hline Jumlah & $20 \%$ & $100 \%$ \\
\hline
\end{tabular}

Hasil evaluasi ketrampilan kader Posyandu dalam mendeteksi kelainan tumbuh kembang anak menunjukkan seluruh kader peserta pelatihan ( 100\% ) mampu melakukannya.

Pertanyaan - pertanyaan yang berkembang selama proses pelatihan adalah :

Bagaimanakah kandungan zat gizi pada makanan yang dihantarkan

Apakah ibu hamil 2 bulan yang minum susu khusus untuk hamil bisa terjadi keracunan, walaupun susu tersebut belum kadaluarsa.

Bagaimanakah penanganan anak autis yang pindah sekolah sampai $3 x$, padahal nilai - nilai pelajarananya baik?

Bagaimanakah cara mencegah kanker leher rahim ? ) penanya punya riwayat nikah pada usia 15 tahun, mengalami $3 x$ keguguran, umur 52 tahun dan masih menstruasi.

Bagaimanakah cara penangganan gerak - gerak reflek pada mata dan bagian tubuh yang lain ? ( penderitaan ada riwayat trauma kepala dan sudah diperiksa EEG )

Bagaimanakah cara penangganan alergi ? apakah harus selalu diminum obat tertentu ?

\section{PEMBAHASAN}

Hasil tersebut di atas menunjukkan bahwa pelatihan tentang deteksi dini kelainan tumbuh kembang anak dapat meningkatkan pengetahuan dan keterampilan ibu dalam mendeteksi kelainan tumbuh kembang anak. Masih ada 4 orang kader ( $80 \%$ ) yang belum menunjukkan peningkatan pengetahuan setelah pelatihan kemungkinan dukungan pengetahuan umum dan latar belakang pendidikan mereka belum memadai serta usia mereka sebagian besar sudah 45 tahun ke atas. Keterampilan seluruh kader Posyandu dalam mendeteksi dini kelainan tumbuh kembang anak setelah pelatihan cukup memadai untuk dapat mengelola posyandu. Para kader mampu melakukan pengukuran antropometri anak, mencatatnya serta menganalisa kurva grafik pertumbuhan anak di KMS. Hal ini merupakan syarat mutlak untuk menjadi seorang kader kesehatan di Posyandu ( Anonim, 2001). Selain itu para kader juga mampu untuk mengamati kelainan fisik dan psikis anak dengan mengamati keadaan dan fungsi fisik anak, serta kondisi perkembangan bahasa dan kecerdasan anak. Kelainan - kelainan yang ditemukan dicatat di KMS apabila perlu penanganan khusus di konsultasi dengan petugas kesehatan dari Puskesmas yang membina Posyandu tersebut. Pada praktek ketrampilan semua kader bisa melakukan pendeteksian tumbuh kembang anak karena mereka sudah cukup lama mengelola Posyandu dan dilakukan secara berkelompok. Masing

- masing kelompok terdiri 4 orang tiap orang di meja -IV. Mereka melakukan pendaftaran, penimbangan pencatatan dan penyuluhan di masing - masing meja. Pada meja IV petugas kesehatan siap menerima konsultansi anak yang mengalami kelainan kesehatan dan tumbuh kembang ( Anonim, 2001 ). Kegiatan PPM ini juga menggunakan metode lomba dalam penilaian

hasil pre-test dan post test. Setiap test kemudian dinilai. Hasil perubahan peningkatan nilai merupakan indikator penentuan juara. Penutupan lomba di akhiri dengan pemberi hadiah berupa peralatan rumah tangga untuk para Juara. Adapun hasil diskusi pada pelatihan ini menunjukkan peningkatan pengetahuan dan respon positif peserta. Dari banyaknya pertanyaan peserta menunjukan bahwa pengetahuan peserta yang semua belum memadai, namun setelah mengikuti pelatihan ternyata ada peningkatan kefahaman tentang konsep kelainan tumbuh kembang anak serta cara pencegahan dan penanggulangannya 


\section{Journal of Community Engagement in Health}

\section{KESIMPULAN}

Ada peningkatan pengetahuan ibu - ibu kader posyandu tentang deteksi dini kelainan tumbuh kembang anak, terbukti sebagian besar ibu - ibu peserta pelatihan mendapatkan nilai post -test lebih tinggi dibanding pre-test.

Keterampilan ibu - ibu peserta pelatihan dalam mendeteksi kelainan tumbuh kembang anak bertambah terbukti semua peserta mampu melakukan tumbuh kembang anak kader.

Wawasan ibu - ibi kader peserta pelatihan hal pencegahan dan penanggulangan kelainan tumbuh kembang anak bertamba terbukti pada diskusi banyak sekali keinginan tahuan mereka tentang cara pencegahan dan penanggulangan kelainana tumbuh kembang anak. Baik sebelum maupun sesudah anak lahir

\section{REFERENSI}

Anonim, 2001. Pedoman Penimbangan Balita di Posyandu, Depkes RI, Jakarta

I Dewa Nyoman Supariasa, 2001. Penilaian Status Gizi, Penerbit Buku Kedokteran EGC, Jakarta.

Roy Meadow \& Simon Newll., 2002, Lecture Notes Pediatrica, Penerbit Erlangga, Jakarta

Soetjiningsih, 1998. Tumbuh Kembang Anak Penerbit Buku Kedokteran EGC, Jakarta Kesehatan Indonesia: Saat Ini dan Masa Depan. Makalah dipresentasikan di STRADA International Conference, Kediri. 